\title{
La modernización de la risa en Costa Rica: Jiménez y Marín Cañas'
}

\section{(The Modernization of Laughter in Costa Rica: Jiménez and Marín Cañas)}

\author{
Grethel Ramírez Villalobos ${ }^{2}$ \\ Universidad Nacional, Costa Rica
}

Gabriel Baltodano Román ${ }^{3}$

Universidad Nacional, Costa Rica

\begin{abstract}
RESUMEN
Se examinan las relaciones entre humor y literatura moderna a partir de dos novelistas costarricenses de inicios del siglo xx: Max Jiménez y José Marín Cañas. En Unos fantoches y en Tú, la imposible se manifiesta el empleo de la risa cínica y la ironía como medios para el análisis artístico de la degradación social y la crisis del hombre moderno. Por su adscripción estético-ideológica, estos relatos implicaron una renovación de las letras costarricenses, alimentada por el contacto con los movimientos históricos de vanguardia y con las estéticas modernas del humor literario.
\end{abstract}

1 Recibido: 12 de setiembre de 2019; aceptado: 31 de enero de 2020. El presente estudio forma parte de los resultados del coloquio Literatura, humor y risa, celebrado en la Facultad de Filosofía y Letras, de la Universidad Nacional (Costa Rica), entre el 3 y el 6 de setiembre de 2018.

2 Escuela de Literatura y Ciencias del Lenguaje. Correo electrónico: grethel.ramirez@una.cr

3 Escuela de Literatura y Ciencias del Lenguaje. Correo electrónico: gabriel.baltodano.roman@una.cr

Letras 68 (2020), ISSN 1409-424X; eISSN 2215-4094 


\begin{abstract}
The relationships between humor and modern literature are examined based on two Costa Rican novelists of the early twentieth century: Max Jiménez and José Marín Cañas. In Unos fantoches and Tú, la imposible, the use of cynical laughter and irony is a means for the artistic analysis of social degradation and the crisis of modern man. Due to their esthetic-ideological orientation, these novels implied a renewal of Costa Rican literature, fueled by contact with avant-garde historical movements and the modern esthetics of literary humor.
\end{abstract}

Palabras clave: literatura costarricense, novela costarricense moderna, risa y literatura, Max Jiménez, José Marín Cañas

Keywords: Costa Rican literature, modern Costa rican novel, laughter and literature, Max Jiménez, José Marín Cañas

\title{
Introducción
}

Durante el primer tercio del siglo $\mathrm{xx}$, se propagaron ideas de renovación artística en Occidente. Entre las abundantes señales del cambio estético descollaron el abandono del afán por imitar la apariencia real, el dominio de lo subjetivo y abstracto, el ejercicio experimental del oficio creativo y la actitud satírica destinada a cuestionar, en particular, las costumbres y los ideales morales de la sociedad burguesa.

Atormentados por el horror de la Gran Guerra (1914-1918), los artistas europeos reaccionaron con indignación y desesperanza. Amplios sectores de la intelectualidad adoptaron los postulados del pensamiento socialista y propugnaron la más honda transformación política y ética. El escepticismo, la disconformidad y el discurso irónico se convirtieron en elementos habituales del arte plástico, el cine, la literatura, la música y el teatro. 
El cubismo de Picasso — que comenzó alrededor de 1907—y la música atonal de Stravinsky y el futurismo de Marinetti que datan de 1909 se anticiparon a la guerra. Sin embargo, participaban de unas exigencias también presentes en el arte posbélico, incluso exaltadas como consecuencia del trauma, a saber: alterar las certidumbres, excitar la sensibilidad, caricaturizar la moral media y combatir la desidia.

En el contexto latinoamericano, el auge económico de Estados Unidos y la ruina de los socios comerciales de ultramar, junto con el proceso de modernización de las repúblicas, dieron lugar, entre los estetas hispanoamericanos, a una serie de discusiones acerca de la necesidad de preservar la identidad, fortalecer la democracia, dignificar al pueblo llano y ensayar nuevas formas expresivas ${ }^{4}$. Las irrupciones de enclaves y monopolios, su influjo en la vida política de las naciones hispanoamericanas, junto a la truncada industrialización, el crecimiento del proletariado urbano y la miseria, y con esto, de las aspiraciones anarquistas y comunistas, crearon un clima de tensiones. Los pensadores creían amenazada no solo la idiosincrasia, sino y más grave, la capacidad de los pueblos para autodeterminarse ${ }^{5}$.

La consolidación del capitalismo en América Latina produjo reticencia. Tanto el programa político como los nuevos modos de vida fueron cuestionados. La libertad creativa guardaba estrictas correspondencias con el encomio de la autonomía colectiva. Fernández Retamar afirma que la producción simbólica de aquel momento histórico desvela las tensiones vividas a propósito del neocolonialismo ${ }^{6}$. Los señalamientos apuntaban, por igual, a la extranjerización y la deshumanización; en Trilce (1922), Altazor (1931), Residencia en la Tierra (1935), obras capitales del vanguardismo hispanoamericano, Vallejo, Huidobro y Neruda

4 Nelson Osorio, ed., Manifiestos, proclamas y polémicas de la vanguardia literaria hispanoamericana (Caracas: Ayacucho, 1998) XxIII.

5 Françoise Pérus, Literatura y sociedad en América Latina: el Modernismo (La Habana: Casa de las Américas, 1976) 65-66.

6 Roberto Fernández Retamar, Para una teoría de la literatura hispanoamericana (La Habana: Pueblo y Educación, 1984) 82. 
enfatizaron la exuberante pluralidad del continente, el temor ante el vacío y el devenir incierto de unos individuos y unas sociedades condenadas a la dependencia.

La reacción ante el lirismo tradicional y la hegemonía oligárquica estuvo vincula con el ascenso de nuevos colectivos humanos? ${ }^{7}$. La clase culta se encargó de dotar a las reivindicaciones sociales de una doctrina precisa. En Costa Rica, ha sido documentada la mentalidad progresista de los intelectuales de la Generación del Repertorio Americano y los nacidos cerca de 1900. En ambos casos, prevalecieron las inquietudes humanistas y una perspectiva acerca de lo social que riñe con la mirada patricia de los escritores aristocráticos ${ }^{8}$. Conviene sumar a este panorama dos hechos simples: primero, el contacto de los artistas de la región con sus homólogos europeos; en especial, durante el periodo inmediato al término de la Primera Guerra Mundial; segundo, los grandes procesos revolucionarios emprendidos en México y Rusia por parte de las masas explotadas. En el primer caso, los creadores hispanoamericanos descubrieron las amplias posibilidades de la expresión estética; en el segundo, una salida política ante la desesperanza de las multitudes.

Los movimientos históricos de vanguardia fueron múltiples y diversos. No basta con advertir diferencias entre las tendencias europeas y americanas; incluso en el interior de los cenáculos hispanoamericanos prevalecían las discrepancias. Tal multiplicidad definía la búsqueda de lo moderno, el capricho de ser otro, y nunca fue obstáculo para la existencia de tesis comunes. Una de ellas se refería, en particular, a la capacidad humana para modelar la historia.

Conviene reconocer que este principio va más allá del conjunto de corrientes vanguardistas; en sentido estricto, se trata de un rasgo definitorio de la mentalidad moderna, realzado por la circunstancias, a saber, pluralidad de ideologías y crisis económicas. La precisión

7 Osorio, xxvIII.

8 Álvaro Quesada Soto, Breve historia de la literatura costarricense (San José: Editorial Costa Rica, 2010) $37-38$. 
puede plantearse de la siguiente manera: en el arte, tal premisa desemboca en un actitud política por parte del creador. Para el intelectual, la sociedad puede hallar en la experiencia estética un medio para superar la enajenación capitalista y favorecer la reivindicación social. El arte emancipaba al hombre, puesto que le devolvía la intensidad del mundo. La representación mimética fue desplazada; no había sitio para las sombras. Las vanguardias tendieron a lo abstracto e irracional; como resultado, impugnaron toda suerte de realismo. Los objetos recordaban lo sublime. El encuentro con lo mecánico modificó a las bellas artes, desembocó en el establecimiento de una dualidad de base: el creador concebía algo, a la vez que lo presentaba; esto era, obra y reflexión acerca del proceso creativo. Imaginar otras realidades suponía antes, descubrir cuán poco cierto era el mundo de las convenciones ${ }^{9}$.

La angustia existencial, el malestar y la rigidez moral solo podían ser superados mediante la independencia absoluta. El artista liberaba la forma, se eximía de los prejuicios, buscaba la novedad y estimulaba la reforma al actualizar la sensibilidad. El arte vanguardista - en una acepción amplia, ajena a nominalismos - comprendía una actitud vital; el carácter subversivo guardaba correspondencias con la incipiente desintegración de los idearios conservadores. Con notable regularidad, el escritor destacaba por su condición de maldito. Se podrá echar en cara el prestigio que, al cabo, cosecharon muchos de los niños terribles del vanguardismo; nada importa: el mercado es omnívoro y la institución, maleable. Un grupo considerable de vanguardistas se oponía a ultranza a toda clase de imposición o norma social; por habitual, simpatizaron con grupos marginados.

Lejos de la confianza en la plenitud de la conciencia, la orientación ilustrada y los usos burgueses, el arte de vanguardias penetraba en los mundos del enajenamiento y el instinto. Tanto las pulsiones como los sueños se convirtieron en objeto de sus discusiones y

9 Jean-François Lyotard, La posmodernidad explicada a los niños (Barcelona: Gedisa, 1999) 20. 
obras; para escapar de la trampa del consumo, se hacía mofa de las imposturas. Al fausto, cosmético de la civilización capitalista, se lo despreciaba tanto como a la retórica preciosista. La búsqueda de la originalidad era empleada como contrapunto. Por intenso, el desarraigo penetró en casi todas las facetas del arte. Producto de la vida moderna y crítico severo de esta, el intelectual devino en ironista. El desprecio por la autocomplacencia y superficialidad burguesas determina una de las grandes constantes del ideario vanguardista. Ha planteado Octavio Paz que en este periodo el creador utilizaba el humor ácido como trinchera ${ }^{10}$.

Ciertas tendencias, más esteticistas y descreídas, concibieron al trabajo creativo como una labor absurda. El caos del cuerpo social, el marasmo ideológico y las manía de la originalidad desembocaron en la constitución de un lenguaje oscuro. La dispersión del significado, un logro de la literatura vanguardista, era alcanzada mediante recursos tales como la ironía y la paradoja; al homologar realidades disímiles e incongruentes, los escritores establecieron cuán indeterminada, vacía y díscola podía ser la existencia. La libertad solo parecía posible para aquellos sujetos y colectivos capaces de comprender la fatuidad de la vida; puesto que la presencia de la cultura tiene mucho de superfluo, el hombre no debía estar atado a ella ni a sus tradiciones. Tal rebeldía produjo una subjetividad basada en antagonismos; entre la angustia de la soledad y el frenesí del libre albedrío, la conciencia se fracturó ${ }^{11}$. A la faceta hermética, la sucede una lengua transparente; al pesimismo, el entusiasmo; y al malestar, el espíritu lúdico.

La quiebra de la noción moderna de sujeto, un ente racional que no cabía en los esquemas de pensamiento posteriores a Nietzsche y Freud, supuso una crisis plena de la modernidad. Como explica Díaz, «en estos nuevos y vitales estadios el artista se encontrará con

10 Octavio Paz, Los hijos del limo (Bogotá: La Oveja Negra, 1985) 88.

11 Saúl Yurkievich, «Los avatares de la vanguardia», Cedomil Goic, ed., Historia y crítica de la Literatura hispanoamericana. Época contemporánea, tomo III (Barcelona: Crítica, 1988) 54. 
grandes paradojas e incertidumbres, e impresionado con aquello que le resultará efímero, fugaz y contigente» ${ }^{12}$. El humor y la acritud no estaban reñidos, podían formar parte de un solo conjunto dispar y caprichoso, a modo de juego amargo.

\section{Transformación y novedad}

En Costa Rica, los informes acerca de las novedades estéticas europeas circularon pronto. Monge ha ofrecido datos de valía para aclarar este punto: «Apuntes sobre la libertad del arte», de Domingo Monge Rojas, publicado por Pandemonium en 1904, refería las grandes transformaciones del panorama creativo; otro artículo titulado «El futurismo», de Guillermo Andreve, recogido por Páginas Ilustradas en 1909, daba cuentas acerca de una de las tempranas tendencias vanguardistas ${ }^{13}$. Supone esto que los intelectuales conocían el fenómeno y se interesaron por las discusiones en boga. La rebeldía ante los modelos anquilosados y el repudio por una tradición desgastada impulsaron un modesto, aunque intenso despertar. Con todo, conviene recordar que la impronta vanguardista fue relativa entre los creadores costarricenses, y la actualización de los medios estéticos demandó el paso de dos décadas enteras. El peso del realismo costumbrista en los relatos y los lastres del Modernismo en la lírica y el teatro afectaron el devenir de las letras costarricenses, ensimismadas en un discurso próximo a los motivos de la identidad o regidas por un canon en desuso.

«Marinetti y el futurismo», artículo de Rubén Darío aparecido en el diario bonaerense La Nación, en abril de 1909, ha sido considerado como la primera nota escrita por un hispanoamericano acerca del naciente movimiento vanguardista. Además de este, dos ensayos

12 Luis Felipe Díaz, Semiótica, psicoanálisis y postmodernidad (Río Piedras: Plaza Mayor, 1999) 99.

13 Carlos Francisco Monge, El vanguardismo literario en Costa Rica (Heredia: Editorial Universidad Nacional, 2005) 17. Vid., además, Guillermo de Andreve, «El futurismo, « Páginas ilustradas (San José) VI, 222 (1909): 3892-3893, referencia tomada de Monge (2005). 
firmados por Amado Nervo, en agosto de 1909, y Leopoldo Lugones, en octubre de 1909, han sido catalogados como fundacionales. Una página, a modo de respuesta, del brasleño Mario de Andrade circuló en mayo, un mes después de la diatriba de Darío y algunos meses antes que las reseñas de los pensadores mexicano y argentino. El conocimiento de las innovaciones artísticas trascendió la noticia esporádica; en casos concretos, fue íntimo. Notables costarricenses viajaron a las más importantes ciudades europeas y los centros cosmopolitas de América Latina, en aras de completar estudios superiores o formarse en campos relativos al arte; la mayoría de ellos había nacido entre 1900 y 1915.

Isaac Felipe Azofeifa viajó a Chile para sus estudios superiores en la enseñanza del castellano; ahí también Carlos Monge Álfaro estudió historia y geografía; Fernando Centeno Güell se formó como psicólogo en España; en ese mismo país, residían José Marín Cañas y Juan Rafael Chacón; Francisco Amighetti emprendió un periplo por América y Max Jiménez se había instalado en París con el objetivo de aprender las técnicas artísticas. El periodo de formación de estos jóvenes coincidió con el apogeo de las manifestaciones vanguardistas. El encuentro con las ideas y expresiones novedosas tuvo una enorme importancia, pues los impulsó a revitalizar el panorama cultural costarricense. Durante los últimos años de la década de 1920, estos personajes propusieron cambios; en algunos casos, la actitud iconoclasta despertó recelos y dificultó la extensión de procesos e conceptos típicos del arte moderno.

En las letras nacionales no se recuerda la existencia de capillas propiamente vanguardistas; se trata, ante todo, de figuras aisladas, aunque con destacada participación e influencia en la vida cultural de la región centroamericana. Con Repertorio Americano (1919) comienza el aglutinamiento de artistas innovadores y el intercambio de impresiones acerca del giro estético. Esta revista se convirtió en un foro de los creadores jóvenes; la labor editorial de Joaquín García Monge favoreció el intercambio de los principios de la nueva 
sensibilidad. El apoyo de García Monge a la generación posterior es contundente; lejos de las preferencias personales, colaboró, por citar un ejemplo, en la publicación de la Unos fantoches (1928), la primera novela de Max Jiménez.

Con el paso de tiempo, la revista varió su naturaleza, pues si bien había empezado como una publicación de carácter literario, acabó por convertirse en una plataforma para el análisis de los problemas sociales y políticos del continente ${ }^{14}$. Además, el Repertorio se caracterizó por la pluralidad estética y la condición de miscelánea; escritos de modernistas, mundonovistas y renovadores ocuparon, por igual, sus páginas. Tal suerte de convivencia heterogénea pudo haber soslayado los enfrentamientos en torno a las perspectivas de los creadores; proclamas y camarillas surgen de la polémica.

La moderna intelección del trabajo creativo se propagó, incluso sin cenáculos. La llegada del vanguardismo fue personalísima, única; a veces, ingenua. Las exploraciones de Max Jiménez y José Marín Cañas ofrecen elocuentes ilustraciones. En Unos fantoches y Tú, la imposible (1931), se percibe el tono experimental y se evidencian resultados desiguales.

En dos decenios se suceden la crisis del imaginario liberal, el crecimiento del medio editorial y la revitalización del ambiente cultural. En este complejo panorama, se sobreponen el legado modernista en el drama y la poesía, el sentir criollo en la narrativa, la prescripción de un canon basado en los logros de la Generación del Olimpo, las posturas políticas de los allegados al Repertorio y los ejercicios abstrusos de los más osados. La incomprensión y la variedad de criterios dominaba el panorama artístico de la Costa Rica de inicios del siglo xx. En pugna con lo asentado, los vanguardistas europeos padecieron la censura y el repudio, a pesar de que se movían en un ámbito mundano

14 Pedro Henríquez Ureña, Las corrientes literarias en la América Hispánica (México: Fondo de Cultura Económica, 1969) 192. 
y abierto. En el espacio nacional, el rechazo tuvo mayor virulencia y desgastó a los creadores. En figuras como Jiménez, este desencuentro entre sociedad y artista alcanzó el nivel del enfrentamiento ${ }^{15}$.

En Candelillas, una colección de sentencias y aforismos, Jiménez resumió algunas premisas de su quehacer artístico; afirmó que «no se puede ser artista y ser sociable» ${ }^{16}$. La aprensión dominaba el entendimiento del creador respecto de la sociedad que le rodeaba; mediante sarcasmo e ironía, el escritor enfiló sus críticas contra las convenciones. Otro axioma suyo planteaba tales cuestiones: «El arte puro es fuego para los falsos valores» ${ }^{17}$. En su opinión, la iconoclasia desempeñaba un papel medular en el desarrollo de la función social del arte moderno. Desde luego, no era a través del realismo como se obtenía una visión precisa de los problemas sociales; era al desestructurar el lenguaje, los géneros y las asociaciones de conceptos, que el mundo recuperaba, ante la percepción del lector, la unicidad. La capacidad de examen de Jiménez excedía los juegos, las mofas y las metáforas hirientes; fue incluso, audaz como pocos al detenerse en un aspecto que escapó a muchos de los artistas modernos: la voracidad con que eran apropiados los nuevos estilos a cuenta y demanda del mercado y el refrescado gusto burgués. Con inusual claridad, al valorar su propia obra pictórica, escribió al respecto:

Mercaderes del arte, en combinación con algunos de «sus genios», han llevado a la pintura a una charlatanería absoluta. Obligando todo noble propósito, a convertirse en imitador de sus genios, para que les sirva así su juventud, de inicua propaganda, y lograr la fácil venta de los disparates que rebosan en sus bodegas ${ }^{18}$.

15 Herrera lo ha planteado de la siguiente manera: «Numerosas paradojas confluyen en el accionar artístico de Max Jiménez: esteta en una sociedad dominada por el pragmatismo, vanguardista en un ambiente cultural por entonces casi inmune a las vanguardias, creador de una obra a menudo mencionada, pero poco conocida y menos estudiada». Ver Bernal Herrera, «El caleidoscopio estético de Max Jiménez», Álvaro Quesada (comp.), Max Jiménez. Aproximaciones críticas (San José: Editorial Universidad de Costa Rica, 1999) 87.

16 Max Jiménez, Obra literaria (San José: Stvdivm, 1982) 541.

17 Jiménez Soto, 568.

18 Max Jiménez, Introducción al libro Max Jiménez, publicado en La Habana (Seoane y Fernández, 
En la literatura, Jiménez probó nuevas formas, apostó por lo sensible e ideó distintas maneras de articular géneros separados por la tradición. La vocación heterodoxa y vanguardista lo condujo al discurso irónico, a un estilo narrativo despojado de ornamentos, limpio, incluso coloquial; un estilo imaginativo, basado menos en la anécdota y más en la provocación.

\section{Max Jiménez}

En su Historia de la literatura costarricense (1957), Abelardo Bonilla trazó un peculiar retrato de Max Jiménez (1900-1947), el principal introductor del vanguardismo literario en el medio nacional. Al leer las páginas dedicadas al escritor, Bonilla ofrece pruebas acerca de su valía y naturaleza incendiaria. Lo confirma cuando sostiene, a propósito de la poesía, que quienes siguen al autor lo hacen cegados por la actitud de renovación ${ }^{19}$. La efigie contiene paradojas; al impulso anarquista, descrito con minuciosidad por Bonilla, lo sigue la adscripción naturalista de los relatos de Jiménez. Era el joven escritor un adelantado o, a pesar de sus pretensiones, seguía atado a una estética pasantista. Con razón, se afirmará que, al emplear el término naturalismo, el crítico se refiere menos a una tendencia y más a una escogencia expresiva. Es cierto; sin embargo, impera la valoración negativa: Bonilla adopta la tesis de Anderson Imbert por encima del juicio de Gabriela Mistral ${ }^{20}$.

1944) a propósito de una exposición realizada en Cuba en 1943. Ha sido tomado de: Álvaro Quesada (comp.), Max Jiménez. Aproximaciones críticas, 111.

19 «Muchos de los jóvenes que hoy escriben versos en Costa Rica han sobreestimado la poesía de Estrada, como la de Max Jiménez, porque situándose en una actitud de renovación, polémica y revolucionaria, ven en estos autores una actitud precursora que necesariamente ha de infundirles simpatía». Abelardo Bonilla, Historia de la literatura costarricense (San José: Editorial Costa Rica, 1967) 194.

20 Bonilla, 154. 
Si se deja atrás esta clase de minucias, se advierte de inmediato cuán clara resultó, en el devenir de las letras costarricense, la dominante en la obra de Jiménez: tanto Unos fantoches como El domador de pulgas y El jaúl son obras satíricas, destinadas a cuestionar las convicciones más asentadas en la sociedad costarricense. La protesta ante la hipocresía burguesa, la falsa redención cristiana y el mito de la arcadia rural forman el espectro temático de estas narraciones. Los recursos literarios (el empleo de grandes metáforas centrales, ironías inestables, deformaciones y la descripción centrada en los aspectos más negativos y groseros) recuerda, por mucho, algunos de los principios generales de la literatura humorística moderna.

Tan incisiva fue su crítica del realismo, que su obra narrativa solo podía concluir con un libro como El jaúl, una inversión radical del cuadro de costumbres ${ }^{21}$. La invectiva contra los usos estéticos corre a la par de la sátira contra el orden social, un «mecanismo regido por un poder arbitrario, por una racionalidad mecánica, que sujeta o encadena los seres humanos a su propio sentido, enajena su inteligencia o voluntad y los constriñe a seguir un papel $\rangle^{22}$. Los relatos de Jiménez ofrecen una imagen irónica de la sociedad de su tiempo; las historias han sido escritas con el propósito de desmitificar las normas, costumbres y convicciones. El espacio costarricense se representa como lugar de degradación, donde los personajes - hombres inútiles, los más de ellos - exhiben vicios y sucumben a causa de su naturaleza malograda. Dos conclusiones preliminares pueden ser consignadas de la siguiente manera: primera, en la faceta estética de la obra narrativa de Jiménez impera el afán por innovar; segunda, la actitud preciosista no riñe con el afán por analizar la realidad nacional, pero desde una perspectiva marcada por la sensibilidad derivada del grotesco romántico y la revolución vanguardista. Aún cuando

21 Flora Ovares y otros, La casa paterna. Escritura y nación en Costa Rica (San José: Editorial Universidad de Costa Rica, 1993) 189.

22 Álvaro Quesada Soto, Uno y los otros. Identidad y literatura en Costa Rica 1890-1940 (San José: Editorial Universidad de Costa Rica, 2002) 169-170. 
sus obras implican una severa revisión de las concepciones criollistas tradicionales, no se abandona el examen de lo inmediato, pero en clave moderna.

El arte vanguardista discutió los problemas de su tiempo. Agobiados por el acontecer inmediato, los escritores dirigían sus ataques contra aquello que los molestaba y formaba parte de sus circunstancias vitales. Unos fantoches, por ejemplo, cuestiona la hipocresía imperante entre los sectores privilegiados; por otra parte, las ponderaciones conservadoras de los lectores costarricenses. La obra misma supone una gran humorada, un artefacto fallido y provocador. Jiménez y Marín Cañas crearon sus novelas como bromas, pues el arte moderno no solo se burla de la tradición, sino que constituye una chanza para el público. El carácter inacabado del texto parte de la tesis que concibe a la obra artística como un experimento; en paralelo, la fragmentación de las secuencias narrativas supone que el receptor debe reorganizar los segmentos del mensaje. Estas dos estrategias guardan interesantes correspondencias con el uso sistemático de la ironía. A esto se suman otras dos categorías: la deformación y la caricatura.

En el plano del significado, la voz fantoche recalca el juicio negativo respecto de los personajes; el sentido es peyorativo, la postura acerca de la naturaleza humana, pesimista. El principio de la deformación parte de una subjetividad exacerbada y del rechazo a los postulados del realismo. Las alteraciones de la forma están vinculadas con las distorsiones morales; caricatura de los hombres es la humanidad, desde la perspectiva del autor. La obra fue compuesta a medio camino entre la novela y el lenguaje teatral; los episodios dispersos aparecen presentados a modo de diálogos correspondientes a personajes específicos; en sentido estricto, no hay tal, pues los parlamentos son mínimos e impera, en cada segmento, la voz de un narrador reflexivo. Esta tendencia es común a la obra de Jiménez, en El domador de pulgas y El jaul, la trama, reducida a lo elemental, se cuenta mediante series de cuadros o escenas, en arreglo con las tablas de grabado que suelen acompañarlos. 
La particularidad de esa primera novela estriba en la teatralidad de tal estructura; se trata de un recurso semejante al empleado por otros vanguardistas hispanoamericanos: narrar la acción dramática ${ }^{23}$. El mundo ficticio refuerza esta clave: la historia se compone de personajes y un retablo traído de vuelta por la memoria del narrador; él mismo tilda a la fábula de comedia protagonizada por fantoches. La vida de esta figuras ocurre al modo de una comedia negra, dominada por bajas pasiones y calumnias. La función crítica de orden ético permite al lector reír a propósito de los desmanes de una sociedad rica pero vacía; en paralelo, de las ponderaciones inoportunas acerca de la calidad de la nueva literatura.

Jiménez acude a la ironía y la caricatura porque de esta manera logra una denuncia más efectiva; puesto que la lacra está asentada en la comunidad, el cuestionamiento puede herir la susceptibilidad colectiva. La estrategia por elegir demanda la complicidad de algunos sectores. En El jaúl, al describir San Luis de los Jaules y sus pobladores, el narrador afirma: «Allí no hay rebelión contra la muerte. No se trata del campesino que ama la tierra y que al morir se une a su madre la tierra. Se trata de un hombre blanco que no se ha integrado» ${ }^{24}$. El deíctico «allí» establece la existencia de un espacio ajeno al lugar imaginario en que se sitúa el narrador y distante del ámbito otorgado al lector. Ese sitio es inhóspito y sus habitantes, detestables; para tranquilidad de emisor y receptor, no los encarcela a ellos. Este procedimiento permite que la sátira se desarrolle bajo los medios de un chiste agresivo, que ataca a un tercero.

El narrador establece una relación de complicidad con el lector; ambos sonríen ante la torpeza de los personajes. La ironía todo lo cuestiona; a los burgueses miopes descritos en Unos fantoches se los denomina «gentes de buena conciencia» ${ }^{25}$. Este uso de la ironía

23 Ver Emir Rodríguez Monegal, «Tradición y ruptura», César Fernández Moreno, ed., América Latina en su literatura (México: Siglo XXI, 1972) 147-151.

24 En el relato titulado «El sol». Max Jiménez, El jaúl (Heredia: Editorial Universidad Nacional, 1998) 23.

25 Max Jiménez, Unos fantoches (San José: El Convivio, 1928) 19 
supone la prevalencia de la conciencia frente al vicio; la fuerza de una ética ajena a las morales, que combate la enajenación y aboga por el libre pensamiento.

«Tomada en tanto que momento subordinado, la ironía es la mirada segura frente a lo torcido, lo equivocado, lo vano de la existencia», afirmó Kierkegaard ${ }^{26}$. El humor de Jiménez es severo; por eso, no es posible encontrar un solo guiño en toda su obra lírica, sobria y menos atractiva, en general. No se pueden comprender las denuncias formuladas por este escritor si se deje de lado la lectura en clave irónica de su obra narrativa. Unos fantoches constituye la puerta al sendero. Si la encrucijada de los vanguardistas tenía por fondo el temor a la enajenación, producto de la sociedad postindustrial, no debe sorprender que hallar a la ironía en muchos de los proyectos emprendidos por estos intelectuales. No es a través de los argumentos y doctrinas que se emancipa al sujeto, esto se logra, de manera efectiva, mediante el cultivo de la duda, al subrayar el malestar y clamar por una nueva sensibilidad.

La presencia de diversos lenguajes y niveles, junto con la apropiación de recursos expresivos novedosos, provoca la perplejidad del lector. Esta obra narrativa escapa al catálogo, resiste las nomenclaturas de su época; sus relatos acerca la novela con el cuento, el ensayo, el poema en prosa, las máximas y el tono expositivo. Escenas y episodios, los pasajes de sus historias obedecen a una unidad más pictórica que literaria. El tópico del artista maldito corre paralelo al carácter incendiario; Jiménez hizo arder buena parte de las persuasiones comunes entre los costarricenses de su época; de manera definitiva, pintó las vanas aspiraciones de una sociedad pueblerina, cristiana y conservadora. Como ha señalado Cortés, su signo es la insatisfacción ${ }^{27}$.

El proyecto artístico de Jiménez se nutre de la confrontación del orden. Mediante el uso reiterado de la ironía, interroga al lector acerca de sus certezas e ingenuidades. El desprecio por las costumbres

26 Sören Kierkegaard, «Sobre el concepto de ironía», Revista de Occidente 221 (1999): 84.

27 Carlos Cortes, La invención de Costa Rica (San José: Editorial Costa Rica, 2003) 126. 
burguesas es solo semejante al fastidio ante los convencionalismos artísticos. Ridiculizar la infamia y las falsas mitologías es uno de los dos principios; el otro consiste en proclamar la libertad creadora, libertad del artista y libertad de la audiencia. La ironía, tenue humor de la ingratitud, está emparentada con ambas búsquedas.

\section{José Marín Cañas}

Próximo a los avatares de su generación, José Marín Cañas (1904-1980) fue un singular escritor. Su contacto con el arte moderno no tuvo la intensidad del vivido por Max Jiménez. Como resultado, la obra narrativa de este autor está impregnada de un espíritu retraído e incierto, aunque no apático ante la novedad. Intermitente en la factura y la estética, este hombre de letras acabó por componer una serie de novelas excepcionales, disímiles e inquietantes. Con el relato «Rota la ternura» (1928), se apartó de la tradición del cuento costarricense. Marín Cañas, aprendiz de preciosista por aquellos días, ensayó un tema nacional bajo un modelo literario de alta calidad estética. La creación de simbolismos, el cuidadoso manejo de la lengua y, en especial, el énfasis en el drama humano, dan al relato un aura de objeto estético, forjado a la luz del arte, que no de las preocupaciones sociales ${ }^{28}$.

Los bigardos del ron (1929) se aparta no solo de la norma en las letras nacionales, sino del estilo previo del escritor. Propuesto como un examen literario de la bohemia, esta colección de cuentos fija el interés en los personajes anómalos y miserables. A partir de la deformación, presenta a figuras desamparadas y sombrías. Este libro recoge dos tendencias afines: por un lado, el oficio de cronista; por el otro, el lirismo exacerbado. Obras posteriores como Coto (1934), El infierno verde (1935) y Pedro Arnáez (1942) pueden ser emblemáticas de tal dualidad creativa. La larga trayectoria periodística de

28 Ver Seymour Menton, El cuento costarricense (México: Ediciones de Andrea / Universidad de Kansas, 1964) 22. 
Marín Cañas no estuvo reñida con el talento poético; caso distinto, fueron facetas complementarias. De este aspecto dan pruebas específicas libros referenciales como Tierra de conejos (1950), extensa crónica de las impresiones españolas del autor, y Valses nobles y sentimentales (1981), una colección de memorias y escritos varios.

Aunque Duverrán ${ }^{29}$ se refiere a esta estética como una suerte de «realismo poético», parece probable y hasta conveniente imaginar otro Marín Cañas más experimental, incluso anterior y, por tanto, primigenio. Se trataría del autor tras Tú, la imposible (1931), una novela aparentemente dispar, con capítulos propios del más exacerbado vanguardismo y largas secciones, de tono neorromántico, lírico y ensimismado. Los dos primeros apartados de la novela entusiasman al lector que busca novedad, pues fueron escritos con un ritmo inmejorable, metáforas ocurrentes y una serie infinita de alusiones al desenfreno y vértigo de la vida moderna; la presentación de las memorias de Juan Aracena es desenfada, burlona y cruel; su amor, el declive de la narración. Sin «continuidad, orden ni hilván» ${ }^{30}$, como señala el proemio, se suceden las angustias y obsesiones del hombre moderno; las cámaras Kodak, los cigarrillos Camel y las estrellas de Hollywood.

Declara el protagonista del relato:

Yo, Juan Aracena, tengo en mal concepto a la Vida. Su belleza, que sostiene a fuerza y maquillaje, me resulta un tanto repulsiva y baja. No soy sindicalista, ni amigo de la Comuna, porque pienso que el día que me haga socialista barreré las calles con una ametralladora skoda. He de confesar que no lo he hecho porque me disgusta romper vidrios. La sociedad en que vivo, donde todos se cotizan por el valor de la corbata que llevan puesta, paréceme un teatro de guignol en el que los muñecos — niñas tontas y bonitas, pollos

29 Carlos Rafael Duverrán, «Prólogo» a Los bigardos del ron (San José: Editorial Costa Rica, 1978) 7.

30 Marín Cañas, Tú, la imposible (San José: Editorial Universidad Estatal a Distancia, 1990) 21. 
imitadores del cine, parlamentarios indigestos de Revolución Francesa, señores que se tronchan los riñones como si todavía estuviésemos en Aranjuez- pierden muy de tarde en tarde el hilo ficticio que los mantiene ${ }^{31}$.

Con una sensibilidad común a los afanes vanguardistas, la primera parte de la novela expone una dura crítica acerca de la burguesía, los esquematismos y las costumbres. Las memorias del hombre triste se refieren, en estos capítulos, menos al desdeñado y más, al excluido. Los seres sensibles solo pueden mirar con tedio la existencia; el narrador admite que su libro es un retrato, no una quimera ${ }^{32}$. El resultado pleno, la novela entera, contradice esta premisa y funda una paradoja. Este hecho no debería asombrar al lector, pues se halla en presencia de una obra experimental. Las novedades no siempre acaban por alcanzar sus cometidos, pueden perder fuerza y deparar estadios intermedios. A pesar de esto, se evidencia una actitud, una manera de representar: el discurso irónico condena los desvaríos de la sociedad moderna.

Marín Cañas fue un joven autor confundido, que perseguía novedades en un medio avejentado; un hombre escindido entre estéticas, que nunca quiso filiaciones; un modernizador sin mayores señas del cambio, que abandonó la reyerta por superflua; un escritor minucioso, reticente a seguir los nuevos usos; un periodista condenado a ejercer su oficio en las páginas de las novelas. Todo esto y algo más: un declarado y fino ironista; basta leer sus artículos de opinión, de ideas otrora debatidas y condenadas bajo el furor ideológico. La biografía dice algo al respecto: se lo recuerda por su ingenio, por su humor vehemente y sincero ${ }^{33}$. En Valses nobles y sentimentales alterna la anécdota simpática con la noticia severa, las andanzas de

31 Marín Cañas, Tú, la imposible, 32.

32 Marín Cañas, Tú, la imposible, 36.

33 Ver Guido Sáenz, «La segunda sonata de Chopin. A la memoria de José Marín Cañas», José Marín Cañas, Realidad e imaginación. Artículos, ensayos, prólogos, conferencias (San José: Hombre y Sociedad, 1974) 71. 
mocedad con el retiro profesional obligado.

La aparente dualidad de Tú, la imposible se disuelve si se considera la novela desde la perspectiva de la risa cínica. El narrador abúlico no es otra cosa que un gran bromista, un hombre inútil, frustrado y misántropo; la novela misma supone una burla, no solo de las convenciones elitistas, sino, además, de los límites del ser humano moderno. La conciencia crítica de su tiempo se despliega, por una parte, como franqueza absoluta - rasgo largamente emparentado con el humor - y, por otra, como sufrimiento. El tema de la clarividencia del derrotado encuentra su contraparte en el espíritu tragicómico de la obra ${ }^{34}$. No son dos secciones, dos novelas (la una vanguardista, la otra romántica); en realidad, se trata de dos movimientos: sindéresis y pathos, sinceridad chocarrera y ensimismamiento, superioridad irónica ante la actualidad e inevitable degradación del hombre moderno. Heredera de la estética del grotesco romántico, la obra reviste una enorme novedad en un medio literario todavía dominado por la risa de los tipos costumbristas y la solemnidad de otras épocas.

Otro asunto suyo, presente en dos de sus grandes novelas, también admite una lectura a partir del empleo del discurso irónico y satírico. Tanto en Coto como en El infierno verde, su autor construye una imagen del nacionalismo. Aquello que empuja a los hombres y las naciones a la guerra solo puede ser comprendido mediante la caricatura, pues es un sentimiento bárbaro, avivado por intereses sórdidos.

En el primero de estos relatos, un grupo de personajes dispares navega por el río; se dirigen al lugar de la avanzada militar y sienten el furor del patriotismo. En la embarcación, uno de los hombres, quizá el menos culpable, ha preparado el fonógrafo, que servirá para hacer oír el Himno Nacional, incluso a los soldados panameños dispuestos a lo largo de la ribera:

34 Ver Luis Beltrán Almería, Estética de la risa. Genealogía del humorismo literario (México: Universidad Veracruzana-Ficticia Editorial, 2016) 47. 
Daniel corrió de nuevo a la proa y le dio nuevamente cuerda al fonógrafo. Parecía que hasta el mismo aparato se enteraba de que la arribada era próxima. Hubo un silencio de anhelo en toda la tripulación. Y con un orgullo, con felicidad, con deseos de abrazar al alguien, la Esperanza enfiló rectamente hacia Coto, con prisa de llegar también. En aquel momento, sonó un disparo. Seco. En nuestra misma cabeza ${ }^{35}$.

La crueldad del episodio remite a un sentido elemental: el patriotismo conduce a la destrucción del hombre, pues lo enajena y vuelve imprudente. El tema de la guerra sirve a este autor para discutir la falta de identidad y criterio propio; atrapado por los mitos y las manipulaciones de los poderosos, el ser humano se lanza en busca de la gloria, y solo encuentra la muerte ${ }^{36}$.

La lección moral propuesta por el ironista se confirma tras la lectura de El infierno verde. En esta novela, los combatientes de uno y otro bando desconocen el origen del impulso que los arrastra a la destrucción. Cegados por el nacionalismo, se pierden entre los límites confusos de El Chaco, un espacio desolador que los consume y cubre con el anonimato. Entre el testimonio de la barbarie, la disertación antibélica y el retrato de la decadencia moral, emerge una cuarta posibilidad: la caricatura del patriotismo. La novela ahonda en el estudio del proceso de la locura; sometidas al peligro permanente, la violencia y el hastío, las figuras del relato sufren graves trastornos anímicos.

Como señala el protagonista, un anónimo soldado paraguayo, «La guerra ha perdido su trágica sinfonía. Ahora la guerra es un silencio que se nos columpia como un zumbido pegado a las orejas». De los cantos patrios y las invocaciones solo quedan los ecos lejanos, las palabras vacías y el horror. Es el discurso social aprobado, fundado en la defensa de la riqueza nacional, el que conduce al hombre a la enfermedad mental. Si bien se expresa mediante un discurso deli-

35 José Marín Cañas, Coto (San José: Editorial Costa Rica, 1976) 57.

36 Carlos Cortés, «Marín Cañas y la guerra del siglo», La Nación, 9 de setiembre de 2007: 4. 
rante, el héroe no es del todo un loco. Para él, los motivos de la guerra son absurdos, inexplicables. A lo largo del viaje por el infierno, descenso a la barbarie impuesta por el instinto de supervivencia, el personaje expresa con claridad su conciencia acerca de la condición en que se halla: ha caído presa de una trampa ${ }^{37}$. Son las palabras de los padres, los caciques y los gobernantes las que carecen de sentido y peso. La arenga nacionalista, abundante en frases falsas, sueltas y confusas, ocupa el lugar del discurso demencial; el protagonista lo escucha en su interior, como una voz impuesta, como una conciencia ajena: «paraguayos al grito de guerra» ${ }^{38}$.

La visión de Marín Cañas va más allá del interés periodístico por los conflictos bélicos, trasciende incluso, el ámbito de la crónica y la mera recreación de las catástrofes. Es una mirada cínica, burlona y descreída, que censura la torpeza y el patriotismo y profundiza en el análisis de las causas. La guerra, tal y como la vivieron muchos de los hombres de la primera mitad del siglo xx, obedece a los impulsos inconscientes, a la racionalidad miope y a la pérdida de la identidad y el libre pensamiento. Así, estas novelas pueden verse como sátiras de las consecuencias del nacionalismo, por una parte, y del drama del hombre moderno, por otra. A modo de respuesta ante los dilemas de su tiempo, esta literatura es humorística, no porque mueva a la risa más bien amarga—, sino porque manifiesta la degradación social que implica, a su vez, la degradación de los personajes y los narradores.

37 Óscar Alvarado, El infierno verde: texto y locura (San José: Editorial Universidad Estatal a Distancia, 2009) 49-50.

38 José Marín Cañas, El infierno verde (San José: Editorial Costa Rica, 1976) 168. 